\title{
The Efficacy of Song Education to Develop English Proficiency for Chinese EFL Majors
}

\author{
Mai Xiaomei ${ }^{1} \&$ Mai Quansheng ${ }^{2}$ \\ ${ }^{1}$ School of English for International Business, Guangdong University of Foreign Studies, Guangzhou, China \\ ${ }^{2}$ Department of Foreign Languages, Guangzhou Vocational School of Tourism and Business, Guangzhou, China \\ Correspondence: Mai Xiaomei, School of English for International Business, Guangdong University of Foreign \\ Studies, Baiyun District, Guangzhou, China.
}

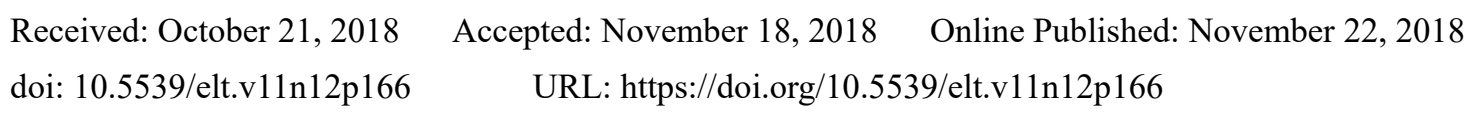

\begin{abstract}
This paper intends to examine the efficacy of song education to develop English proficiency in China's EFL context. By conducting a comparative study between two parallel classes and analyzing the results of forty-eight questionnaires, the paper reveals the following: 1) song education can help improve pronunciation and intonation skills to a great extent; 2) only carefully selected songs can be evidently helpful with the acquisition of vocabulary and grammar; and 3) song education makes it possible for students to be more culturally informed and culturally interested. Thus this paper casts some light on how song education can be employed as an effective strategy to develop English proficiency for English majors in China.
\end{abstract}

Keywords: song education, musical intelligence, English proficiency, Chinese EFL majors

\section{Introduction}

Educators and researchers are seen to have employed songs to develop language proficiency to varying degrees for the past few decades. The reason for this practice mainly lies in the assertion that songs can help language learning.

When it comes to the origin of language, hypotheses concerning human beings' singing capabilities are first put forward by Rousseau in the $18^{\text {th }}$ Century and then by Humboldt in the $19^{\text {th }}$ Century (Yao, 1995). Later, Vaneechoutte and Skoyles (1998) propose the "memetic origin of language", viewing humans as "musical primates". Vaneechoutte (2014) takes one step forward to modify his musical origin of articulate language theory by analyzing the overlap between linguistic and musical abilities.

Gardner (1983) finds that musical intelligence is one of the eight major intelligences which define human intellect from a multidimensional perspective. The theory of Multiple Intelligences enriches the concept of Intelligent Quotient (IQ), the traditional measurement of human intellect which focuses solely on linguistic and logical-mathematical intelligences. Gardner (2006) further contends that his theory is a cognitive revolution, "a synthesis of work" in such fields as neuroscience and anthropology. People with relatively high musical intelligence may not necessarily be musicians or conductors; however, they are normally sensitive to rhythm, tone, pitch, timbre and melody (Gardner, 1983). Such terms as "rhythm", "tone" and "pitch" indeed resemble the phonological features of language. Musical intelligence can be partly innate and partly developed (Gardner, 1983). And some research has already been done to explore the correlation between music education and English language acquisition.

Firstly, some research is undertaken where English is considered the native language. Blanton (1962) studies the effect of music education on the acquisition of language among Year 1 and Year 2 elementary school students. Hoskins (1988) surveys pre-school children aged two to five with certain language barriers. In both surveys, children with some music education show better sound discrimination and articulation skills. Later, Vaneechoutte and Skoyles (1998) put forward the "music-acquiring device" in contrast to Chomsky's prevailing theory of "language-acquisition device".

Secondly, part of the research concerned examines the above-mentioned correlation in countries or areas regarding English as a foreign language (EFL), English as a second language (ESL) and English as an additional language (EAL). Murphey (1990) points out the positive association between song and language, claiming that 
the use of songs could be a preferable strategy for language acquisition. Murphey (1992) continues his research by compiling a corpus of 50 English songs from the Music and Media Hot 100 Charts. And this lexical analysis helps to conclude that popular songs as a text genre are affective, short, dialogic, lexically simple and repetitive with vague references (Murphey, 1992). In another empirical study, five EAL pupils are taught six Western songs to evaluate their spoken English level. By the $6^{\text {th }}$ week, all five participants show a significant improvement in their English speech and vocabulary study within the musical learning context (McCormack \& Klopper, 2016).

Thirdly, apart from the research conducted by scholars from abroad, some studies of the correlation between music education and EFL acquisition are also found in China. Qian (1993) unveils from the aesthetic linguistics perspective that 1) melody and rhythm constitute the common core of both the phonetic system and the musical sound system; and 2) speech events tend to be musicalized to some degree in pursuit of beauty of speech. Duan (1997) contends that a good music education is positively correlated with better pronunciation and intonation. Yuan (2002) discusses the feasibility and principles of introducing popular songs into college English teaching. Pei $(2003,2013)$ gains some insight into 1) the positive correlation between musical intelligence and English listening and speaking achievements; and 2) the impact of musical aptitude on the phonological acquisition of first-year non-English majors in China. Liu et al. (2008) report Chinese EFL learners' achievements largely from the cultural perspective, based on years of elective courses in English Songs and Cultural Studies.

From the above-mentioned studies, we can see certain revelation of the positive correlation between music education and English language acquisition. However, much of the research is done with pre-school kids, elementary children and vocational school students as survey subjects. Not sufficient research has been conducted with university students, let alone Chinese EFL majors.

Songs are usually sung by the human voice with melody and lyrics. And either the appreciation or the singing of songs is considered part of the music education which indicates certain musical intelligence (Gardner, 1983). Thus this paper sets out to study some issues in this regard.

For brevity's sake, the term "song education" is made the working definition for this research to refer to the melodic singing, appreciation and analysis of English songs during the EFL teaching-learning process. Specific research questions to be addressed in this paper are as follows: 1) Can English majors in Chinese universities benefit from song education? 2) In what aspects can song education help improve students' English proficiency? 3) To what extent is song education better than traditional EFL teaching-learning in terms of learners' achievements?

\section{Method}

\subsection{Participants}

The present research is conducted with forty-eight first-year English majors in Semester 2 of an academic year in Guangdong University of Foreign Studies. Participants are from two parallel classes with the same teacher for a full academic year. There are twenty-four students respectively in each of the two classes. These students share almost the same English proficiency, as is indicated by their final test scores of Comprehensive English Course by the end of Semester 1 of the same academic year. One class is randomly made the experimental group and the other the control group.

In Semester 1, the learning-by-doing method is adopted to teach both groups. And students begin the study of each unit with listening and speaking activities, followed by an intensive reading passage, an extensive reading passage as well as a reading/writing model. Students are also asked to finish vocabulary practices, translation exercises and writing tasks for better comprehension of each unit.

In Semester 2, the control group continues to learn in the conventional teaching context. However, apart from the same learning tasks as the control group, the experimental group is additionally introduced to a list of English songs with each different unit topic as shown in Table 1.

Table 1. Songs introduced to the experimental group

\begin{tabular}{llll}
\hline Unit topic & Song title & Artist(s) & $\begin{array}{l}\text { Year } \\
\text { release }\end{array}$ \\
\hline Animals and plants & Donna Donna & Joan Baez & 1960 \\
& April come she will & Simon \& Garfunkel & 1966 \\
& Puff & Peter, Paul and Mary & 1963 \\
\hline
\end{tabular}




\begin{tabular}{|c|c|c|c|}
\hline & Lemon tree & The Brothers Four & 1981 \\
\hline & Where have all the flowers gone & The Kingston Trio & 1961 \\
\hline \multirow{4}{*}{$\begin{array}{l}\text { Environmental } \\
\text { protection }\end{array}$} & Earth song & Michael Jackson & 1995 \\
\hline & Big yellow taxi & Joni Mitchell & 1970 \\
\hline & Heal the world & Michael Jackson & 1991 \\
\hline & $\begin{array}{l}\text { Turn! Turn! Turn! (To everything there is a } \\
\text { season) }\end{array}$ & The Byrds & 1965 \\
\hline \multirow[t]{9}{*}{ National identity } & Englishman in New York & Sting & 1987 \\
\hline & Born in the U.S.A. & Bruce Springsteen & 1984 \\
\hline & Russians & Sting & 1985 \\
\hline & Ebony and ivory & $\begin{array}{l}\text { Paul McCartney \& Stevie } \\
\text { Wonder }\end{array}$ & 1982 \\
\hline & Brothers in arms & Dire Straits & 1985 \\
\hline & Give peace a chance & Plastic Ono Band & 1969 \\
\hline & Do they know it's Christmas? & Band Aid & 1984 \\
\hline & We are the world & United Support of Artists & 1985 \\
\hline & The APL song & Black Eyed Peas & 2003 \\
\hline \multirow[t]{7}{*}{ Marriage and family } & Home & Michael Bublé & 2005 \\
\hline & Stand by me & Ben E. King & 1961 \\
\hline & Ain't no sunshine & Bill Withers & 1971 \\
\hline & I Swear & All-4-One & 1994 \\
\hline & Don’t cry, Joni & $\begin{array}{l}\text { Conway Twitty \& Joni } \\
\text { Twitty }\end{array}$ & 1975 \\
\hline & Both sides now & Joni Mitchell & 2000 \\
\hline & Grow old with me & John Lennon & 1980 \\
\hline \multirow[t]{7}{*}{ Fashions } & Fashion & Lady Gaga & 2009 \\
\hline & Mountains O’Mourne & Don McLean & 1973 \\
\hline & Fashion & David Bowie & 1980 \\
\hline & Candle in the wind 1997 & Elton John & 1997 \\
\hline & Gangsta's paradise & Coolio & 1995 \\
\hline & Empire state of mind & Jay-Z \& Alicia Keys & 2009 \\
\hline & All this useless beauty & Elvis Costello & 1996 \\
\hline \multirow[t]{8}{*}{ Movies } & Yellow Submarine & The Beatles & 1966 \\
\hline & $\begin{array}{l}\text { Lucy in the sky with diamonds } \\
\text { (From "Yellow Submarine" OST) }\end{array}$ & The Beatles & 1967 \\
\hline & Blowin' in the wind & Bob Dylan & 1963 \\
\hline & Fortunate son & $\begin{array}{l}\text { Creedence } \\
\text { Revival }\end{array}$ & 1969 \\
\hline & Sloop John B & The Beach Boys & 1966 \\
\hline & California dreamin' & The Mamas \& the Papas & 1965 \\
\hline & $\begin{array}{l}\text { San Francisco (Be sure to wear some } \\
\text { flowers in your hair) }\end{array}$ & Scott McKenzie & 1967 \\
\hline & $\begin{array}{l}\text { Respect } \\
\text { (From “Forrest Gump" OST) }\end{array}$ & Aretha Franklin & 1967 \\
\hline
\end{tabular}




\subsection{Procedure}

This empirical study maintains that the instructor's teaching, students' in-class and out-of-class learning efforts are all integral and significant parts of the teaching-learning process. Thus the introduced songs are studied during each session in the following way:

To begin with, there are the in-class teaching-learning activities. When listening to a song the experimental group is provided with necessary guidance and explanations. Students are first asked to focus on the melody, together with the phonological handling of lyrical content. Then students are led to analyze the lyrics, so as to understand the theme and cultural message thus conveyed.

Next, out-of-class learning efforts would follow: 1) students are required to practise the melodic singing of the songs in their spare time, bearing in mind the key points mentioned earlier in class; and 2) students are encouraged to appreciate songs of the same artist, theme or genre.

\subsection{Data Collection}

The final test of Comprehensive English Course in Semester 1 is considered the pre-test, and the final test by the end of Semester 2 of the same course is made the post-test in this study.

In addition, every one of the forty-eight students is invited to complete an anonymous questionnaire with fifteen questions under three categories in the $16^{\text {th }}$ week of Semester 2, with the aim of knowing whether and how song education can help improve students' English proficiency. And comment on each category of statements is also welcome. As for the evaluation of second language proficiency, Stern (1983) summarizes several approaches. However, he admits that there is no single convincing standard for evaluating second language proficiency. This paper thus sets out to include both linguistic and communicative aspects from the phonological, lexico-grammatical and cultural perspectives. And the Likert scale is adopted to investigate respondents' level of agreement or disagreement to the questionnaire statements.

\section{Results}

\subsection{Data from Pre-test and Post-test}

The average score of the pre-test for the experimental group is 78.6 (100 in total) and that of the control group is 78.3 , with a slight difference of 0.3 point between the average scores of the two groups. When Semester 2 ends, progress has been spotted in both groups. The average score of the post-test for the experimental group is 84.5 , as compared to a lower 81.4 of the control group. Thus a relatively significant difference of 3.1 points has been notified.

\subsection{Data from Questionnaires}

Results from questionnaires are shown in the following six tables. The answers "strongly agree" and "agree" are considered acceptance, while "strongly disagree" and "disagree" are held as rejection.

Table 2. Phonological gains of the experimental group

\begin{tabular}{llcccc}
\hline Statements & $\begin{array}{l}\text { Strongly } \\
\text { Agree }\end{array}$ & Agree & Neutral & Disagree & $\begin{array}{l}\text { Strongly } \\
\text { Disagree }\end{array}$ \\
\hline $\begin{array}{l}\text { 1. I can better identify word stress and } \\
\text { sentence stress. }\end{array}$ & $46 \%$ & $42 \%$ & $13 \%$ & $0 \%$ & $0 \%$ \\
$\begin{array}{l}\text { 2. I get more familiar with the weak forms of } \\
\text { function words. }\end{array}$ & $38 \%$ & $50 \%$ & $8 \%$ & $4 \%$ & $0 \%$ \\
$\begin{array}{l}\text { 3. I am better acquainted with the various } \\
\text { ways of linking. }\end{array}$ & $50 \%$ & $42 \%$ & $8 \%$ & $0 \%$ & $0 \%$ \\
$\begin{array}{l}\text { 4. I can better manage the rhythm of English } \\
\text { speech. }\end{array}$ & $46 \%$ & $46 \%$ & $4 \%$ & $4 \%$ & $0 \%$ \\
$\begin{array}{l}\text { 5. I understand various intonation patterns } \\
\text { better. }\end{array}$ & $46 \%$ & $42 \%$ & $8 \%$ & $0 \%$ & $4 \%$ \\
\hline
\end{tabular}


Table 3. Phonological gains of the control group

\begin{tabular}{llllll}
\hline Statements & $\begin{array}{l}\text { Strongly } \\
\text { Agree }\end{array}$ & Agree & Neutral & Disagree & $\begin{array}{l}\text { Strongly } \\
\text { Disagree }\end{array}$ \\
\hline $\begin{array}{l}\text { 1. I can better identify word stress and } \\
\text { sentence stress. }\end{array}$ & $42 \%$ & $38 \%$ & $13 \%$ & $4 \%$ & $4 \%$ \\
$\begin{array}{l}\text { 2. I get more familiar with the weak forms of } \\
\text { function words. }\end{array}$ & $38 \%$ & $42 \%$ & $21 \%$ & $0 \%$ & $0 \%$ \\
$\begin{array}{l}\text { 3. I am better acquainted with the various } \\
\text { ways of linking. }\end{array}$ & $42 \%$ & $42 \%$ & $17 \%$ & $0 \%$ & $0 \%$ \\
$\begin{array}{l}\text { 4. I can better manage the rhythm of English } \\
\text { speech. }\end{array}$ & $33 \%$ & $46 \%$ & $13 \%$ & $4 \%$ & $4 \%$ \\
$\begin{array}{l}\text { 5. I understand various intonation patterns } \\
\text { better. }\end{array}$ & $42 \%$ & $38 \%$ & $13 \%$ & $4 \%$ & $4 \%$ \\
\hline
\end{tabular}

Table 4. Lexico-grammatical gains of the experimental group

\begin{tabular}{|c|c|c|c|c|c|}
\hline Statements & $\begin{array}{l}\text { Strongly } \\
\text { Agree }\end{array}$ & Agree & Neutral & Disagree & $\begin{array}{l}\text { Strongly } \\
\text { Disagree }\end{array}$ \\
\hline 6. I enlarge my vocabulary considerably. & $42 \%$ & $42 \%$ & $13 \%$ & $4 \%$ & $0 \%$ \\
\hline 7. I understand the choice of words better. & $38 \%$ & $46 \%$ & $8 \%$ & $4 \%$ & $4 \%$ \\
\hline $\begin{array}{l}\text { 8. I know how to punctuate a sentence } \\
\text { better. }\end{array}$ & $33 \%$ & $50 \%$ & $8 \%$ & $4 \%$ & $4 \%$ \\
\hline $\begin{array}{l}\text { 9. I can identify good sentences more } \\
\text { quickly. }\end{array}$ & $38 \%$ & $46 \%$ & $13 \%$ & $0 \%$ & $4 \%$ \\
\hline $\begin{array}{l}\text { 10. I improve my understanding of } \\
\text { rhetorical devices. }\end{array}$ & $42 \%$ & $46 \%$ & $4 \%$ & $8 \%$ & $0 \%$ \\
\hline
\end{tabular}

Table 5. Lexico-grammatical gains of the control group

\begin{tabular}{|c|c|c|c|c|c|}
\hline Statements & $\begin{array}{l}\text { Strongly } \\
\text { Agree }\end{array}$ & Agree & Neutral & Disagree & $\begin{array}{l}\text { Strongly } \\
\text { Disagree }\end{array}$ \\
\hline 6. I enlarge my vocabulary considerably. & $38 \%$ & $42 \%$ & $17 \%$ & $4 \%$ & $0 \%$ \\
\hline 7. I understand the choice of words better. & $46 \%$ & $38 \%$ & $8 \%$ & $4 \%$ & $4 \%$ \\
\hline $\begin{array}{l}\text { 8. I know how to punctuate a sentence } \\
\text { better. }\end{array}$ & $42 \%$ & $38 \%$ & $17 \%$ & $0 \%$ & $4 \%$ \\
\hline $\begin{array}{l}\text { 9. I can identify good sentences more } \\
\text { quickly. }\end{array}$ & $42 \%$ & $42 \%$ & $17 \%$ & $0 \%$ & $0 \%$ \\
\hline $\begin{array}{l}\text { 10. I improve my understanding of } \\
\text { rhetorical devices. }\end{array}$ & $46 \%$ & $38 \%$ & $13 \%$ & $0 \%$ & $4 \%$ \\
\hline
\end{tabular}

Table 6. Cultural gains of the experimental group

\begin{tabular}{llcccc}
\hline Statements & $\begin{array}{l}\text { Strongly } \\
\text { Agree }\end{array}$ & Agree & Neutral & Disagree & $\begin{array}{l}\text { Strongly } \\
\text { Disagree }\end{array}$ \\
\hline $\begin{array}{l}\text { 11. I get to know various traditions and } \\
\text { customs better. }\end{array}$ & $38 \%$ & $44 \%$ & $17 \%$ & $0 \%$ & $0 \%$ \\
$\begin{array}{l}\text { 12. I learn to respect different values and } \\
\text { beliefs. }\end{array}$ & $46 \%$ & $46 \%$ & $8 \%$ & $0 \%$ & $0 \%$ \\
$\begin{array}{l}\text { 13. I am better informed of certain social } \\
\text { issues. }\end{array}$ & $46 \%$ & $42 \%$ & $8 \%$ & $0 \%$ & $4 \%$ \\
\hline
\end{tabular}




\begin{tabular}{llllll} 
14. I become more culturally sensitive. & $50 \%$ & $38 \%$ & $8 \%$ & $4 \%$ & $0 \%$ \\
$\begin{array}{l}\text { 15. I develop an intense interest in cultural } \\
\text { studies. }\end{array}$ & $38 \%$ & $54 \%$ & $4 \%$ & $0 \%$ & $0 \%$ \\
\hline
\end{tabular}

Table 7. Cultural gains of the control group

\begin{tabular}{llllll}
\hline Statements & $\begin{array}{l}\text { Strongly } \\
\text { Agree }\end{array}$ & Agree & Neutral & Disagree & $\begin{array}{l}\text { Strongly } \\
\text { Disagree }\end{array}$ \\
\hline $\begin{array}{l}\text { 11. I get to know various traditions and } \\
\text { customs better. }\end{array}$ & $42 \%$ & $42 \%$ & $13 \%$ & $4 \%$ & $0 \%$ \\
$\begin{array}{l}\text { 12. I learn to respect different values and } \\
\text { beliefs. }\end{array}$ & $38 \%$ & $42 \%$ & $8 \%$ & $8 \%$ & $4 \%$ \\
$\begin{array}{l}\text { 13. I am better informed of certain social } \\
\text { issues. }\end{array}$ & $33 \%$ & $38 \%$ & $17 \%$ & $4 \%$ & $8 \%$ \\
$\begin{array}{l}\text { 14. I become more culturally sensitive. } \\
\begin{array}{l}\text { 15. I develop an intense interest in cultural } \\
\text { studies. }\end{array}\end{array}$ & $38 \%$ & $50 \%$ & $8 \%$ & $4 \%$ & $4 \%$ \\
\hline
\end{tabular}

\section{Discussion}

\subsection{Phonological Gains}

Data from Table 2 and Table 3 report progress of the two groups from the phonological perspective: 1) $88 \%$ of the respondents from the experimental group think they can better identify stressed and unstressed words, as compared to $80 \%$ of the control group; 2) $88 \%$ get more familiar with strong forms and weak forms of function words, as compared to $80 \%$; 3) $92 \%$ are better acquainted with the various ways of linking, as compared to $84 \%$; 4) $92 \%$ can better manage the rhythm of English speech, as compared to $79 \%$; and 5) $88 \%$ understand various intonation patterns better, as compared to $80 \%$.

English is known as a stress-timed language, which distinguishes itself from Chinese, a typical syllable-timed language (Wang, 2002). Thus it is not surprising to find English learners in China articulate English sentences with the wrong rhythmic pattern. Earlier in Semester 1, students from both groups are introduced to the following basic knowledge of English pronunciation and intonation: the articulation of phonetic symbols, word stress, sentence stress, strong forms and weak forms of function words, ways of achieving linking, tone groups, pausing, and different types of English intonation.

The answers to Statement 1 indicate that Chinese EFL learners can better identify stressed and unstressed words through song education. Qian (1993) points out that the te-tum te-tum rhythm is preferred by English native speakers. To better handle the English speech prosody, the training of sentence stress is of utmost importance. Without proper training, students tend to articulate every English word in a sentence with the same length and strength (Li, Wang, \& Yang, 2013). It is understandable that, with sufficient exposure to English songs, students get to know how stressed and unstressed words are produced.

The experimental group also reacts more positively to Statement 2 on the efficacy of song education. Chinese students do not often realize the importance of weak forms of function words without proper training. Native speakers of the English language find it unpleasant to listen to an "all-strong form" speech. What is more, the difficulty of understanding English speech would also arise from the unfamiliarity of weak forms (Wang, 2002). Two students from the experimental group comment that they learn from singing in ways of reducing or eliminating sounds, and obscuring vowels towards the schwa. In particular, they find the frequent use of the schwa is the key to the study of weak forms.

A higher percentage of respondents from the experimental group give positive response to Statement 3. Linking or sound liaison is what makes the English speech smooth and natural. Both groups are taught with different types of linking earlier in Semester 1. By the end of Semester 2, the experimental group reports that they become more acquainted with linking and have less difficulty in native speech comprehension. Five students from the experimental group comment that they recognize the frequent use of the linking-r or intrusive-r, as compared to just one respondent from the control group. 
The answers to Statement 4 suggest that there exists a positive correlation between the rhythmic patterns of language and song. Duan (1997) holds that foreign language majors in China need to practise the singing of songs in addition to mere phonological rectifying. Not only music and songs have rhythmic patterns, but every language has its own unique rhythm (Murphey, 1990). You (2004) proposes that the similarities mainly lie in the integrated use of stress, tone groups and pausing. Feedback from students identifies with such an argument. 92\% of the experimental group, in contrast to $79 \%$ from the control group, report that they can better understand how the English rhythmic pattern works after one semester's song education. That is to say, song education indeed helps EFL learners to better handle speech prosody.

Feedback from Statement 5 reveals that students in general welcome additional songs to improve their intonation skills. This is quite understandable. Melody and rhythm belong to the common core of the phonetic system as well as the musical sound system (Qian, 1993). Intonation is further defined as the melody of language (Wang, 2002). In this sense, songs, with melody as one typical feature, have something in common with languages. Survey findings show that more students from the experimental group realize the positive transition from English songs to English speech. Two students in the experimental group comment that song education is particularly helpful when it comes to the perception of pitch changes in the falling-rising tone.

To sum up, survey results show that the experimental group is more skilful in dealing with various phonological aspects.

\subsection{Lexico-grammatical Gains}

Statistics from Table 4 and Table 5 report gains from the lexico-grammatical perspective of the two groups: 1) $84 \%$ of the respondents from the experimental group think they enlarge their vocabulary considerably, as opposed to $80 \%$ of the control group; 2) $84 \%$ of the respondents from each group believe they understand the choice of words better; 3) $84 \%$ know how to punctuate a sentence better, as opposed to $80 \%$; 4) $84 \%$ of the respondents from each group believe they can identify good sentences more quickly; and 5) $88 \%$ think they improve their understanding of rhetorical devices, as opposed to $84 \%$.

Response to Statement 6 from the experimental group is slightly better than that of the control group. This has much to do with the lexical coverage of popular songs. The "song-stuck-in-my-head" phenomenon is described by Murphey (1990) as a "melodic Din", which is associated with the involuntary musical and verbal rehearsal in the mind. Murphey (1992) goes on to reveal in his lexical analysis that popular songs as a text genre are short, lexically simple and repetitive with vague references. Tegge (2017) further examines the vocabulary load of English songs with two popular song corpora and concludes that there exists the need of a graded system of song lyrics for English learners of various proficiency levels.

Response to Statement 7 reveals no difference in learning achievements. The choice of words may include the ability to identify formal and informal words, specific and concrete words, idiomatic and unidiomatic expressions, and shades of difference between synonyms. One typical feature of English song lyrics may be the frequent use of dialogic or informal words (Murphey, 1992). This may bring some confusion for EFL learners. Rap songs or hip-hop songs, for example, usually include expressions of Ebonics popular with Afro-Americans.

Acceptance with Statement 8 from the experimental group is again slightly better than that of the control group. What is more, one student from the experimental group mentions that some texts of song lyrics pay little or no attention to capitalization and punctuation. To avoid confusion, teachers should carefully choose the list of songs for students.

Response to Statement 9 suggests no difference in students' learning achievements. A good sentence is first structurally complete and grammatically correct, and then effective enough to address such needs as unity, support and coherence (Langan, 2012). It is understandable that certain popular songs may fall short of meeting such requirements with their lyrics being casually written to cater for the so-called "snack culture".

The answers to Statement 10 reveal that Chinese EFL learners come to realize the value of songs as a poetic expression. Still a blind spot in the printed "high literature", songs are actually an active and important part of modern literature with its artistic expression (Moser, 2007). Bob Dylan, winner of the 2016 Nobel Prize in Literature, has highlighted this poetic expression to the world as a marvelous singer-songwriter. Moreover, four students from the experimental group comment that various rhetorical devices have been deployed in song lyrics writing. This is true. For instance, the rhetorical device of rhyming is found in nearly every song. As is suggested by the "triple beauty" theory, rhyming chiefly brings out the prosodic beauty in poetic translation (Xu, 1983). When it comes to the poetic expression of songs, rhyming also adds to the prosodic beauty of lyrics.

In conclusion, the experimental group considers song education slightly beneficial for the acquisition of 
vocabulary and grammar. In other words, not all songs are evidently helpful when it comes to lexico-grammatical gains.

\subsection{Cultural Gains}

Results from Table 6 and Table 7 identify progress from the cultural perspective of the two groups: 1) $84 \%$ of the respondents from each group believe they get to know various traditions and customs better; 2) $92 \%$ of the experimental group learn to respect different values and beliefs, in contrary to $80 \%$ of the control group; 3 ) $88 \%$ are better informed of certain social issues, in contrary to $71 \%$; 4) $88 \%$ are more attentive to youth culture, in contrary to $83 \%$; and 5) $92 \%$ develop an intense interest in cultural studies, in contrary to $84 \%$.

Response to Statement 11 suggests an identical level of learning achievements of the two groups. Hu (1991) advocates that learning a foreign language is learning a new culture, and conventional teaching does contribute to cultural learning in terms of norms and traditions. Another reason might be that popular songs do not usually care about social customs as traditional literature does. Though it is less likely to find Billboard songs to relate to a specific social custom, country songs may serve as an exception.

A much higher percentage of respondents from the experimental group give positive answers to Statement 12 . The list of songs mainly covers the musical creation of American and British artists. American artists' works in the post-WWII era, in particular, witness a coexistence of values and beliefs among different races (Liu et al., 2008). Not surprisingly, one respondent from the experimental group notifies the same observation.

The experimental group also responds more positively to Statement 13. Songs can be event-oriented to include the feminist movement in the 1950s and 1960s, the civil rights movement in the 1960s, the anti-war movement in the late 1960s and early 1970s, and the aid for Africa in the 1980s, to name but a few.

The answers to Statement 14 indicate, to a certain degree, the positive correlation between song education and cultural sensitivity. It is interesting that three respondents from the experimental group mention "California dreaming" coincidently, a term they find most impressive from songs of the 1960s. And the key to interpreting America in the 1960s does lie in the essence of anti-establishment or counterculture (Liu et al., 2008).

Acceptance with Statement 15 from the experimental group is again better than that of the control group. Interest is said to be the best teacher in the learning process. In this sense, the song education study can be considered a rewarding experience for it has aroused an intense interest in cultural studies. One student from the experimental group mentions that she is hugely fascinated by the song "Yellow Submarine", and she continues to explore on her own such cultural phenomena as "Beatlemania" and "British Invasion".

Generally speaking, respondents from the experimental group believe that song education offers them a deeper understanding of cultural issues.

\section{Conclusion}

This empirical study reveals that song education can be employed as an effective strategy in EFL teaching and learning. With sufficient and proper exposure to English songs, first-year English majors in China can better develop English proficiency to varying degrees.

When the specific efficacy of song education is concerned, phonological and cultural achievements turn out to be relatively notable, followed by less lexico-grammatical gains. First, the English majors believe that, to quite an impressive extent, song education indeed helps improve their English pronunciation and intonation skills stress, weak forms, linking, rhythm of speech and intonation patterns. Besides, respondents regard song education as slightly helpful for lexico-grammatical gains. Compared with traditional EFL teaching, only carefully selected songs can be evidently helpful with the acquisition of vocabulary and grammar. Thus teachers of song education need to be especially careful in this regard. What is more, English majors recognize more cultural gains. Song education make it possible for them to be better informed of various norms and traditions, values and beliefs as well as social issues, and to develop a keener cultural sensitivity and a stronger interest in cultural studies.

However, some limitations are also found in this research. First, all of the respondents are from the same university, which might affect the validity of the research results to some extent. Second, the research can be further supported by learning achievements of the respondents in a longer period of time. Third, there could be some more discussion of the standard for song selection.

Taken into consideration the limitations of this paper, future study in this regard may recruit respondents from different universities. Long-term learners' achievements from the phonological, lexico-grammatical and cultural perspectives can also be investigated. What is more, a relatively detailed discussion of the standard for song 
selection can be initiated.

\section{References}

Blanton, W. L. (1962). An experimental application of language theory, learning theory, and personality theory to evaluate the influence of music in language learning. Dissertation Abstracts, 23(1), 351-352.

Duan, R. L. (1997). Effect of musical aptitude on pronunciation and intonation of foreign languages. Journal of Xi'an International Studies University, 2.

Gardner, H. (1983). Frames of mind: The theory of multiple intelligences. New York: Basic Books New edition.

Gardner, H. (2006). On failing to grasp the core of MI theory: A response to Visser et al. Intelligence, 34, 503-505. https://doi.org/10.1016/j.intell.2006.04.002

Hoskins, C. (1998). Use of music to increase verbal response and improve expressive language abilities of preschool language delayed children. Journal of Music Therapy, 25(2), 73-84. https://doi.org/10.1093/jmt /25.2.73

Hu, W. Z. (1991). Learning a foreign language is learning another culture. The World of English, 6.

Langan, J. (2012). College writing skills with readings (6th ed.). Foreign Language Teaching and Research Press.

Li, X. G., Wang, G. Z., \& Yang, S. Z. (2013). Research on objective evaluation system of English sentences based on stressed syllables and prosody. Computer Engineering and Applications, 49(8), 105-109. https://doi.org/10.3778/j.issn.1002-8331.1108-0398

Liu, Y., Fan, W. J., Li, X. M., \& Mai, X. M. (2008). English songs and cultural studies. Xi'an Jiaotong University Press.

McCormack, B. A. \& Klopper, C. (2016). The potential of music in promoting oracy in students with English as an additional language. International Journal of Music Education, 34(4), 416-432. https://doi.org/10.117 $7 / 0255761415619066$

Moser, S. (2007). Media modes of poetic reception Reading lyrics versus listening to songs. Poetics, 35, 277-300. https://doi.org/10.1016/j.poetic.2007.01.002

Murphey, T. (1990). The song stuck in my head phenomenon: A melodic din in the LAD? System, 18(1), 53-64. https://doi.org/10.1016/0346-251X(90)90028-4

Murphey, T. (1992). The discourse of pop songs. TESOL Quarterly, 26(4), 770-774. https://doi.org/10.2307/358 6887

Pei, Z. W. (2003). Effect of musical intelligence on English listening and speaking. Journal of Xi'an International Studies University, 11(3). https://doi.org/10.16362/j.cnki.cn61-1457/h.2003.03.012

Pei, Z. W. (2012). Review of foreign research on the effect of musical aptitude on the second language phonological acquisition. Contemporary Foreign Languages Studies, 2.

Pei, Z. W., \& Ding, Y. R. (2013). Empirical study on the effect of musical aptitude on Chinese university students' phonological abilities. Foreign Language World, 1.

Qian, G. L. (1993). Aesthetic linguistics: the beautiful: language and speech. Haitian Publishing House

Stern, H. H. (1983). Fundamental Concepts of Language Teaching. Oxford University Press.

Tegge, F. (2017). The lexical coverage of popular songs in English language teaching. System, 67, 87-98. https://doi.org/10.1016/j.system.2017.04.016

Vaneechoutte, M. (2014). The Origin of Articulate Language Revisited: The Potential of a Semi-Aquatic Past of Human Ancestors to Explain the Origin of Human Musicality and Articulate Language. Human Evolution, 29, 1-33.

Vaneechoutte, M., \& Skoyles, J. R. (1998). The Memetic Origin of Language: Modern Humans as Musical Primates. Journal of Memetics - Evolutionary Models of Information Transmission, 2.

Wang, G. Z. (2002). English pronunciation and intonation for communication. Higher Education Press.

Xu, Y. C. (1983). Second study on "message beauty, prosodic beauty, image beauty". Foreign Language Research, 4. https://doi.org/10.16263/j.cnki.23-1071/h.1983.04.011

Yao, X. P. (1995). Humboldt: research of humanism and languages. Foreign Language Teaching and Research Press. 
You, C. H. (2004). Similarities between music rhythm and English rhythm. Journal of Xi'an International Studies University, 12(3). https://doi.org/10.16362/j.cnki.cn61-1457/h.2004.03.011

Yuan, X. L. (2002). Introducing music into college English teaching: feasibility and principles. Wuhan University Journal (Humanity Sciences), 55(1), 108-112. https://doi.org/10.3969/j.issn.1671-881X.2002.01.018

\section{Appendix}

Questionnaire: English proficiency survey

Table A1. Phonological gains

\begin{tabular}{|c|c|c|c|c|c|}
\hline Statements & $\begin{array}{l}\text { Strongly } \\
\text { Agree }\end{array}$ & Agree & Neutral & Disagree & $\begin{array}{l}\text { Strongly } \\
\text { Disagree }\end{array}$ \\
\hline $\begin{array}{l}\text { 1. I can better identify word stress } \\
\text { and sentence stress. }\end{array}$ & & & & & \\
\hline $\begin{array}{l}\text { 2. I get more familiar with the } \\
\text { weak forms of function words. }\end{array}$ & & & & & \\
\hline $\begin{array}{l}\text { 3. I am better acquainted with the } \\
\text { various ways of linking. }\end{array}$ & & & & & \\
\hline $\begin{array}{l}\text { 4. I can better manage the rhythm } \\
\text { of English speech. }\end{array}$ & & & & & \\
\hline $\begin{array}{l}\text { 5. I understand various intonation } \\
\text { patterns better. }\end{array}$ & & & & & \\
\hline
\end{tabular}

Comment

Table A2. Lexico-grammatical gains

\begin{tabular}{|c|c|c|c|c|c|}
\hline Statements & $\begin{array}{l}\text { Strongly } \\
\text { Agree }\end{array}$ & Agree & Neutral & Disagree & $\begin{array}{l}\text { Strongly } \\
\text { Disagree }\end{array}$ \\
\hline $\begin{array}{l}\text { 6. I enlarge my vocabulary } \\
\text { considerably. }\end{array}$ & & & & & \\
\hline $\begin{array}{l}\text { 7. I understand the choice of } \\
\text { words better. }\end{array}$ & & & & & \\
\hline $\begin{array}{l}\text { 8. I know how to punctuate a } \\
\text { sentence better. }\end{array}$ & & & & & \\
\hline $\begin{array}{l}\text { 9. I can identify good sentences } \\
\text { more quickly. }\end{array}$ & & & & & \\
\hline $\begin{array}{l}\text { 10. I improve my understanding } \\
\text { of rhetorical devices. }\end{array}$ & & & & & \\
\hline
\end{tabular}

Comment 
Table A3. Cultural gains

\begin{tabular}{l|llll}
\hline Statements & $\begin{array}{l}\text { Strongly Agree } \\
\text { Agree }\end{array}$ & Neutral & Disagree & $\begin{array}{l}\text { Strongly } \\
\text { Disagree }\end{array}$ \\
\hline 11 I get to know various & & & \\
traditions and customs better. & & & \\
12. I learn to respect different & & & \\
values and beliefs. & & & \\
13. I am better informed of & & & \\
certain social issues. & & & \\
14. I become more culturally & & & \\
sensitive. & & & \\
15. I develop an intense interest & & & \\
in cultural studies. & & & \\
\hline
\end{tabular}

Comment

\section{Copyrights}

Copyright for this article is retained by the author(s), with first publication rights granted to the journal.

This is an open-access article distributed under the terms and conditions of the Creative Commons Attribution license (http://creativecommons.org/licenses/by/4.0/). 